\title{
MANAJEMEN STRATEGI EKONOMI PADA LEMBAGA PENDIDIKAN ISLAM
}

\author{
Ivan Riyadi \\ Universitas Islam Negeri (UIN) Raden Fatah Palembang \\ Email: ivanriyadi_uin@radenfatah.ac.id
}

\begin{abstract}
This article is written based on unique considerations in theworld of education and economic strategies in Islamic educational institutions. This research proposes a strategic framework that can help evaluate the relationship and linkages between economic strategies and Islamic education institutions. The evaluation is expected to be a material consideration in the management of economic strategies, so that the performance of Islamic education institutions can be improved. Institutional performance is evaluated using criteria that include productivity, cost reduction, innovation, reactivity, responsiveness, and collaboration. To get a complete picture in this article, a qualitative approach with the study of literature is used. The results of the study show that evaluating the relationship of economic strategy management in Islamic education institutions uses a framework. management functions include; planning, organizing, directing and controlling. Therefore, management is defined as the process of planning, organizing, leading, and controlling the efforts of the organization with all its aspects so that organizational goals are achieved effectively and efficiently
\end{abstract}

Keywords : Credit Management, Partnership and Community Development Programs

\section{DASAR PEMIKIRAN}

Lembaga pendidikan Islam memiliki kekuatan tersendiri dalam kalangan umat Islam, karena lembaga pendidikan Islam merupakan salah satu lembaga pendidikan tertua di Indonesia. Lembaga pendidikan islam memiliki pengaruh pengaruh yang besar dalam kehidupan sosial masyarakat. Lembaga pendidikan islam memiliki fungsi sentral dalam masyarakat karena umumnya lembaga pendidikan islam merupakan perwujudan aspirasi umat Islam. Lembaga pendidikan islam memiliki berbagai macam tujuan dan program yang secara ideal bertujuan memelihara prilaku keagamaan.

Seiring dengan kemajuan informasi dan teknologi, terlebih ketika dihadapkan pada era globalisasi, menurut Dindin Jamaluddin, dunia pendidikan di Indonesia menghadapi tantangan yang sangat serius.Menurutnya.( Dindin Jamaluddin' 2013:187 ) Penyiapan terhadap generasi penerus bangsa yang berkarakter merupakan kebutuhan yang amat vital, karena karakter yang baik tidak terbentuk secara otomatis Hal ini 
52 | Ivan Riyadi Manajemen Strategi Ekonomi Pada Lembaga Pendidikan Islam....•

dilakukan untuk mempersiapkan tantangan global dan daya saing bangsa.( Weinata Sairin, 2001: 211 ). Tujuan utama peningkatan kinerja ini adalah untuk mewujudkan niat dan tujuan mulia lembaga dalam menciptakan out put peserta didik yang memiliki kecerdasan di bidang keilmuan, keimananan dan berakhlak mulia. Tidak dapat dipungkiri bahwa perkembangan teknologi informasi yang sedemikian cepat tidak saja mengubah cara orang berkomunikasi dan bekerja, namun lebih jauh lagi telah membuat alam persaingan baru.

Manajemen merupakan suatu proses ilmu untuk merencanakan, mengorganisasikan, memimpin, dan mengendalikan upaya organisasi dengan segala aspeknya agar tujuan organisasi tercapai secara efektif dan efisien (Nanang Fatah, 2004: 1). Pada hakikatnya, manajemen merupakan proses penggunaan sumber daya secara efektif untuk mencapai sasaran atau tujuan tertentu ( Muhaimin, dkk'2009:04 ). Malayu S.P.Hasibuan berpendapat bahwa manajemenmerupakan ilmu, seni yang mengatur proses pemanfaatan sumberdaya manusia beserta sumber-sumber lainnya secara efektif danefisien untuk mencapai suatu tujuan tertentu (Malayu S.P Hasibuan, 2001: 2) Sedangkan menurut Stoner sebagaimana dikutip oleh Handoko manajemen adalah proses perencanaan, pengorganisasian, pengarahan dan pengawasan terhadap kegiatan yang dilakukan oleh para anggota organisasi dan penggunaan sumber daya organisasi lainnya agar mencapai tujuan yang telahditetapkan (T. Hani Handoko'2003: 08).

Dalam rangka mempersiapkan tuntutan global tersebut, maka lembaga pendidikan yang tersebar di penjuru Indonesia, khususnya lembaga pendidikan Islam yang berada di tingkat pusat, daerah terus melaksanakan berbagai upaya peningkatan kinerja dari seluruh komponen madrasah/sekolah agar memiliki keunggulan bersaing. Sehingga lembaga pendidikan islam masalah ekonomi tidak lagi jadi permasalahan. Karena telah menjalankan manajemen strategi ekonomi dalam dunia pendidikan.

Kondisi tersebut menciptakan jurang yang amat dalam dan curam karena perkembangan zaman dan teknologi begitu cepat perubahan dalam sektor ekonomi Nasional dituntut lembaga pendidikan islam harus mengikut perubahan tersebut. Perubahan tersebut harus berjalan secara seiringan dan harmonis karena keduanya 
merupakan mata rantai yang tidak dapat dipisahkan. Manajemen strategi ekonomi pada lembaga pendidikan islam sebagai pranata sosial Islam sekaligus media rahmatan lil 'alamin hanya akan mewujudkan rahmat yang diidam-idamkan jika lembaga pendidikan islam berfungsi mengikuti kekinian masyarakat. Diperlukan manajemen ekonomi dalam dunia pendidikan.

Adapun kegelisahan akademik dalam penelitian ini adalah kondisi penyelenggaraan lembaga pendidikan islam etimologi maupun semantik belum memahami kesatuaan manusia secara esensial diperlukan rumusan manajemen strategi ekonomi pada lembaga pendidikan islam. Dari fokus permasalahan tersebut, yaitu 1) Bagaimana peran manajemen strategi ekonomi dalam lembaga pendidikan Islam dan 2) Seberapa signifikan manajemen strategi ekonomi dalam lembaga pendidikan islam melihat hubungan antara perkembangan dunia pendidikan dan sektor ekonomi masyarakat. Dari rumusan masalah tersebut, maka tujuan dari penelitian ini adalah merumuskan tentang peran peran manajemen strategi ekonomi dalam lembaga pendidikan Islam dan memberikan rumusan hubungan signifikan.Melalui peran peran manajemen strategi ekonomi dalam lembaga pendidikan Islam. Pada dataran empirik akan dapat dilihat serat-seratnya dan latar belakang ekonomi dan pendidikan tersebut muncul dan dirumuskan. Melalui tawaran rumusan tersebut agama nampak akrab dan dekat dengan masalah-masalah manusia dan berupaya menjelaskan dan memberikan jawabannya.

\section{METODOLOGI PENELITIAN}

Artikel ini menggunakan metode studi literatur (literature study), pencarian hasil riset ataupun sebuat teori yang berkaitan dengan pembahasan dalam artikel yang sedang dikaji. Sehingga teori-teori dan hasil penelitian tentang manajemen pendidikan Islam, strategi bisnis, lembaga pendidikan islam, teori masyarakat majemuk, sosial

Adapun referensi diperoleh melalui laporan penelitian khususnya yang sudah dipublikasikan, jurnal nasional ataupun artikel internasional, buku, adapun prosedur dalam penelitian literatur tersebut melalui tiga tahapan yaitu; pertama pengumpulan, keduaanalisis data, ketigapenarikan kesimpulan. Tanpa ingin mengklaim sebagai kemutlakan kebenaran hasil kajian, kita juga dituntut berupaya menemukan rumusan 
54 | Ivan Riyadi Manajemen Strategi Ekonomi Pada Lembaga Pendidikan Islam.....

tentang dari pendekatan kebahasaan hingga tinjauan istilah, secara substansial maupun fungsional.

\section{KAJIAN LITERATUR}

Dalam penelitian Fanny Paylosa dengan judul pengaruh strategi bisnis dan desentralisasi terhadap hubungan antara pemanfaatan informasi sistem akuntasi manajemen dan kinerja manajerial (studi empiris pada perusahaan jasa perhotelan di kota padang dan bukit tinggi) ( Fanny Paylosa,2014: 03 ). Penelitian ini bertujuan untuk menguji pengaruh informasi system akutansi manajemen dan kinerja manajerial.Hasil penelitian ini menunjukkan bahwa terdapat pengaruh tersebut begitu signifikan.Pertumbuhan ekonomi dan implikasi globalisasi membuat semua jenis bidang usaha bersaing dengan ketat.Dalam ketidakpasitian yang tinggi manajemen harus memiliki alat untuk membantu mereka dalam merencanakan dan mengalokasikan sumber daya yang terbatas.

Dalam buku Dwinrandra kesesuaian antara desentralisasi dengan informasi sistem akutansi manejemn akan mampu memeperbaiki kinerja manejerial (Dwirandra, 200: 01 ). Kesesuain dua aspek tersebut berasosiasi dengan kinerja lebih tinggi.Hal ini terjadi karena para manajerial lebih senang dievaluasi dengan ukuran kinerja.Berdasarkan uraian di atas peneliti menduga bahwa desentralisasi sebagai variable pemoderasi berpengaruh positif terhadap hubungan antara informasi sistem akutansi manajemen terhadap kinerja manajerial.

Dalam jurnal Rahayu Puji Suci dengan judul peningkatan kinerja melalui orientasi kewirausahaan, kemampuan manajemen, dan strategi bisnis (studi pada industri kecil menengah bordir di jawa timur) ( Rahayu Puji Suci, 2009: 50 ) Manfaat yang didapat dari penelitian ini yaitu: (1) bagi pengembangan ilmu pengetahuan, hasil penelitian ini diharapkan dapat menjadi bahan bacaan dan informasi dalam penelitian lebih lanjut maupun dalam mengembangkan ilmu pengetahuan, terutama yang berkaitan dengan kinerja. (2) bagi IKM bordir di Jawa timur dengan diketahui orientasi entrepreneur industry kecil menengah di jawa timur maka diharapkan dapat disusun suatu bentuk pengembangan intreprenuer. (3) bagi pemerintah, hasil penelitian ini diharapkan dapat digunakan sebagai masukan bagi pemerintah khususnya pemerintah propinsi jawa timur 
Ekonomica Sharia Volume 5 Nomor 1 Edisi Agustus $2019 \mid 55$

dalam mengembangkan dan membina IKM bordir yang ada di jawa timur. (4) bagi peneliti, hasil peneliti ini akan menambah pengetahuan dan wawasan peneliti terutama dalam masalah yang berkaitan dengan IKM dalam kemampuan manajemen, strategi bisnis, orientasi kewirausahaan dan kinerja.

\section{HASIL DAN PEMBAHASAN}

\section{Peran Manajemen Strategi Ekonomi Pada Lembaga Pendidikan Islam}

Manajemen strategi ekonomi digunakan untuk memantau produktifitas kerja sumber daya manusia pada lembaga pendidikan islam. baik yang berorientasi produksi jasa maupun pelayanan. Demikian halnya perwujudan kinerja yang membanggakan juga sebagai imbalan intrinsik. Hal ini akan berlanjut terus dalam bentuk kinerja berikutnya, dan seterusnya. Agar dicapai kinerja yang profesional maka perlu dikembangkan hal-hal seperti: kesukarelaan, pengembangan diri pribadi, pengembangan kerjasama saling menguntungkan, serta partisipasi seutuhnya. Hal itu akan terjadi jika seorang pimpinan mengetahui tentang faktor-faktor yang mempengaruhi terhadap kinerja bawahannya.

Pemberdayaan ekonomi masyarakat sekolah adalah penguat pemilikan factor-faktor produksi, penguatan penguasaan distribusi dan pemasaran, penguatan masyarkat untuk mendapatkan gaji/upah yang memadai dan penguatan masyarakat sekolah memperoleh informasi, pengetahuan dan keterampilan yang harus dilakukan secara multi aspek, baik dari aspek masyarakatnya sendiri, maupun aspek kebijakan. Menurut Robert L. Mathis dan John H.Jackson (2002: 82). faktor-faktor yang mempengaruhi kinerja individu tenaga kerja, yaitu; kemampuan mereka, motivasi, dukungan yang diterima, keberadaan pekerjaan yang merekalakukan, dan hubungan mereka dengan organisasi. Sedangkan Maisah menjabarkan faktor-faktor yang mempengaruhi kineja seseorang meliputi;( Martinis Yamin dan Maisah, 2010:129-130). Faktor personal/individual, meliputi unsur pengetahuan, keterampilan (skill), kemampuan, kepercayaan diri, motivasi, dan komitmen yang dimiliki oleh tiap individu guru. Hal itu akan terjadi jika seorang 
56 | Ivan Riyadi Manajemen Strategi Ekonomi Pada Lembaga Pendidikan Islam.....

pimpinan mengetahui tentang faktor-faktor yang mempengaruhi terhadap kinerja bawahannya. Menurut Fakhry Zamzam dan Havis Aravik (2016: 80) faktor-faktor yang mempengaruhi kinerja individu tenaga kerja, yaitu; kemampuan mereka, motivasi, dukungan yang diterima, keberadaan pekerjaan yang mereka lakukan, dan hubungan mereka dengan organisasi.

Konsep mengenai pemberdayaan ekonomi masyarakat menurut hutomo dari beberapa program atau proyek pemberdayaan masyarakat dalam bidang ekonomi antara lain: (1) bantuan modal (2) bantuan bangunan prasarana (3) bantuan pendampingan (4) penguatan kelembagaan (5) penguatan kemitraan usaha.( Hutomo Mardi Yatmo, 2000: 15 ) Konsep tersebut sangat cocok untuk dijadikan program pemberdayaan masyarakat sekolah dalam memenuhi kebutuhan sekolah.

Sedangkan Maisah menjabarkan faktor-faktor yang mempengaruhi kineja seseorang meliputi; ( Anwar Prabu Mangkunegara, 2000: 67 ).

1. Faktor personal/individual, meliputi unsur pengetahuan, keterampilan(skill), kemampuan, kepercayaan diri, motivasi, dan komitmen yang dimiliki oleh tiap individu guru

2. Faktor kepemimpinan, meliputi aspek kualitas manajer dan team leader dalam memberikan dorongan, semangat, arahan dan dukungan kerja padabawahannya

3. Faktor tim, meliputi kualitas dukungan dan semangat yang diberikan oleh rekan dalam satu tim, kepercayaan terhadap sesame anggota tim, kekompakan dan keeratan anggotatim

4. Faktor sistem, meliputi sistem kerja, fasilitas kerja yang diberikan oleh pimpinan, proses organisasi dan kultur kerja dalam organisasi.

\section{Pengaruh Manajemen Strategi Ekonomi Pada Lembaga Pendidikan Islam}

Pengaruh manajemen strategi pada lembaga pendidikan Islam yaitu; faktor kemampuan (ability) dan faktor motivasi (motivation) yang dijelaskan sebagai berikut;

1. Faktor kemampuan. Secara psikologis, kemampuan (ability) pegawai terdiri 
atas kemampuan potensi (IQ) dan kemampuan realita pendidikan. Oleh karena itu, pegawai perlu ditempatkan pada pekerjaan yang sesuai dengankeahliannya kepada hasil yang diinginkannya itu. Artinya, apabila seseorang sangat menginginkan sesuatu, maka akan terbuka jalan untuk memperolehnya, sehingga yang bersangkutan termotivasi oleh keinginannya dan akan berupaya untuk mendapatkannya. (Sondang P. Siagian, 2002: 292 ) Motivasi merupakan kondisi yang menggerakkan pegawai ke arah pencapaiantujuan.

2. Sikap mental, merupakan kondisi mental yang mendorong seseorang untuk berusaha mencapai potensi kerja secara maksimal. Berdasarkan pendapat tersebut, dapat disimpulkan bahwa kinerja karyawan dipengaruhi oleh faktor internal maupun faktor eksternal seorang karyawan. Faktor eksternal tersebut sangat erat kaitannya dengan situasi atau kondisi kerja pada suatu perusahaanatau organisasi, salah satunya mengenai masalah konflik yang terjadi.Manajer yang efektif akan memanfaatkan sumber daya organisasi sedemikian rupa, sehingga membuahkan hasil kerja yang baik serta kepuasan bagi mereka yang ikut serta dalam melaksanakan pekerjaan yang diperlukan. Terdapat dua kriteria yang berhubungan dengan suatu kinerja masing-masing, yaitu efektivitas dan efisiensi,( John R. Schermerhorn, Jr, 2003: 05 ). sebagaimana gambar berikut;

3. Terdapat dua kategori dasar atribusi: yang bersifat internal atau disposisional (dihubungkan dengan sifat-sifat orang), dengan yang bersifat ekternal atau situsional (yang dapat dihubungkan dengan lingkungan seseorang). Misalnya, perilaku (dalam hal ini kinerja) dapat ditelusuri hingga ke faktorfaktor spesifik seperti kemampuan, upaya, kesulitan tugas, atau nasib baik. Kemampuan dan upaya adalah penyebab-penyebab yang bersifat internal bagi ekternal. Meskipun demikian, sejumlah faktor lain dapat juga mempengaruhi kinerja, seperti perilaku, sikap dan tindakan-tindakan rekan kerja bawahan, atau pimpinan; kendala-kendala sumber daya; keadaan ekonomi; dansebagainya.( A. Dale Timpe2002: 32-33 )

Faktor motivasi (Malayu S.P Hasibuan, 2007:141 ) Faktor ini terbentuk dari 
58 | Ivan Riyadi Manajemen Strategi Ekonomi Pada Lembaga Pendidikan Islam.....

sikap (attitude) seorang pegawai dalam menghadapi situasi kerja. Motivasi merupakan akibat dari suatu hasil yang ingin dicapai oleh seseorang, dan perkiraan seseorang yang bersangkutan bahwa tindakannya akan mengarah.

Pengaruh manajemen strategi ekonomi dalam pendidikan islam terlibat beberapa komponen pokok yang ditampilkan oleh seorang pimpinan, yaitu; perencanaan (Planning), pengorganisasian (Organizing), pemimpinan (Leading), dan pengawasan (Controlling). Sedangkan menurut Husaini Usman (210:15) fungsi manajemen meliputi; perencanaan, pengorganisasian, pengarahan dan pengendalian. Oleh sebab itu, manajemen diartikan sebagai proses merencanakan, mengorganisasi, memimpin, dan mengendalikan upaya organisasi dengan segala aspeknya agar tujuan organisasi tercapai secara efektif danefisien.( Nanang Fattah, 2001: 02 ).

Manullang berpendapat bahwa dalam manajemen terdapatunsur perencanaan, pembuatan keputusan, pengorganisasian, dan penyempurnaan (M. Manullang \& Marihot Amh Amnullang, 2008:04). Sedangkan menurut Ngalim Purwanto meliputi; perencanaan, organisasi, koordinasi, komunikasi, supervisi kepengawasan pembiayaan dan evaluasi.(Ngalim Purwanto, 2010:14) Berbagai pendapat tersebut, pada hakikatnya dikembalikan kepada empat bagian, yang dijabarkan sebagai berikut; Perencanaan (planning): budgeting, programming, decision making, forcasting, Pengorganisasian (organizing): structuring, assembling resources, staffing, Penggerakan (actuating): coordinating, directing,commanding,motivating, leading, stimulating, motivating, Pengawasan (controlling):monitoring, appraising, evaluating, reporting (Hendyat Soetopo, 2001: 04).

Sedangkan kinerja dimaknai sebagai sesuatu yang dicapai, prestasi yang diperlihatkan dan kemampuan kerja (A. Tabrani Rusyan \& Wasmin,2008:48) Kinerja merupakan indikator keberhasilan personil, tim, atau suatu unit organisasi dalam mewujudkan sasaran yang telah ditetapkan oleh organisasi dengan perilaku yang diharapkan.( Mulyadi,2007:337) Adapun definisi kinerja menurut para ahli sebagai berikut;

1) Menurut Tika, kinerja dimaknai sebagai hasil kegiatan seseorang atau 
kelompok pada suatu organisasi yang dipengaruhi oleh berbagai faktor untuk mencapai tujuan organisasi dalam waktu tertentu (Moh Pabundu Tika,2007: 67).

2) Menurut Mangkunegara, (2007: 67) kinerja adalah hasil kerja secara kualitas dan kuantitas yang dicapai oleh seorang pegawai dalam melaksanakan tugasnya sesuai dengan tanggung jawab yang akan diberikankepadanya.

3) Kinerja (performance) menurut MahsunMohammad Mahsun, (2006: 25) adalah gambaran mengenai tingkat pencapaian pelaksanaan kegiatan atau program dalam mewujudkan sasaran, tujuan, misi dan visi organisasi yang tertuang dalam perencanaan strategi organisasi. Kinerja yang ditunjukkan oleh individu sering digunakan untuk menyebut prestasi dan tingkat keberhasilan individu dalam melaksanakan kegiatanorganisasi.

Berangkat dari hal tersebut di atas, maka manajemen kinerjadapat dimaknai sebagaisuatu proses menciptakan pengertian tentang apa yang harus, bagaimana mencapainya dan suatupendekatan mengelola orang untuk meningkatkan kemungkinan pencapaian hasil yang berhubungan dengan pekerjaan (Ahmad S. Ruky, 2002:05). Hal ini menunjukkan bahwa, manajemen kinerja yang dilakukan olehlembaga pendidikan madrasah, menurut Simanjuntak Payaman (2005: 17 ) bertujuanuntuk meningkatkan kinerja sebuah organisasi melalui keseluruhan kegiatan yang dilakukannya

\section{KESIMPULAN}

Peran manajemen strategi ekonomi pada lembaga pendidikan Islam dapat dijelaskan sebagai berikut: Persaingan antar lembaga pendidikan yang sudah ada (rivalry among existing institution). Ancaman dari lembaga pendidikan pendatang baru (threat of new entrant). Ancaman dari lembaga pendidikan yang menawarkan jasa pendidikan pengganti (threat of substitute educations service). Kekuatan tawarmenawar pemasok/masyarakat yang membutuhkan jasa pendidikan (Bargainning Power of Suppliers).Kekuatan tawar-menawar pembeli (Bargaining Power of Buyer) Berangkat dari hal tersebut, dapat diketahui bahwa lembaga pendidikan Islam akan 
60 | Ivan Riyadi Manajemen Strategi Ekonomi Pada Lembaga Pendidikan Islam.....

memiliki competitive adventage (keunggulan bersaing) jika manajamen kinerjanyadi samping aspek yang laindikelola dengan baik, sesuai dengan situasi dan latar yang mengelilinginya.

Pengaruh manejemen strategi ekonomi pada lembaga pendidikan islam di atas menunjukkan bahwa kinerja adalah catatan mengenai akibat-akibat yang dihasilkan pada sebuah fungsi pekerjaan atau aktivitas selama periode tertentu yang berhubungan dengan tujuan organisasi. Kinerja yang ditunjukkan oleh individu pada suatu organisasi merupakan gabungan dari kompetensi, usaha dan kesempatan yang dapat diukur dari akibat yang dihasilkannya. Oleh karena itu, kinerja ukan menyangkut karakteristik pribadi yang ditunjukkan oleh seseorang melalui hasi kerja yang telah dan akan dilakukan seseorang.( Khaerul Umam, 2010: 186 )Kinerja dapat pula diartikan sebagai kesuksesan individu dalam melakukan pekerjaannya. Ukuranpekerjaannya yang spesifik dalam bentuk aktivitas selama kurun waktu tertentu. Dengan kata lain, ukuran kesuksesan kinerja tersebut didasarkan pada ukuran yang berlaku dan disesuaikan dengan jenis pekerjaannya. 
Ekonomica Sharia Volume 5 Nomor 1 Edisi Agustus $2019 \mid 61$

\section{DAFTAR PUSTAKA}

A. Tabrani Rusyan \& Wasmin, 2008. Etos Kerja dalam Meningkatkan Produktivitas Kinerja Guru, Jakarta: PT. Intimedia Ciptanusantara.

A.A. Anwar Prabu Mangkunegara, 2007, Manajemen Sumber Daya ManusiaPerusahaan, Bandung : PT Remaja Rosdakarya

Ahmad S. Ruky, 2002, Sistem Manajemen Kinerja, Jakarta: Gramedia Pustaka Utama.

Hendayat Soetopo, 2001, Manajemen Pendidikan, Malang: Uniersitas Negeri Malang.

Husnaini Usman, 2010, Manajemen: Teori, Praktek dan Riset Pendidikan, Jakarta: Bumi Aksara.

KhaerulUmam, 2010,PerilakuOrganisasi,Bandung:PustakaSetia.

M. Manullang dan Marihot Amh Amnullang, 2002, Manajemen Personalia, Yogyakarta: Gajah Mada University Press

Malayu S.P. Hasibuan, 2007, Manajemen Sumber Daya Manusia, Jakarta: Bumi Aksara.

Moh. Pabundu Tika, 2006. Budaya Organisasi dan Peningkatan Kinerja Perusahaan, Jakarta: Bumi Aksara.

Mohammad Mahsun, 2006, Pengukuran Kinerja Sektor Publik, Yogyakarta: BPFE: Yogyakarta.

Mulyadi, 2007, Sistem Perencanaan dan Pengendalian Manajemen, Jakarta: Salemba Empat.

Nanang Fattah, Landasan Manajemen Pendidikan., hlm. 2

Ngalim Purwanto, 2010, Administrasi dan Supervisi Pendidikan (Bandung : Remaja Rosdakarya.

Payaman J. Simanjuntak, 2005, Manajemen dan Evaluasi kinerja, Jakarta: Fakultas Ekonomi UI.

A Dale Timpe, 2002, Manajemen Sumber Daya Manusia Kinerja, Jakarta: Gramedia.

A.F.Stoner, 1982,ManagementNewYork:Frentice/HallInternational,Inc,Englewood.

Anwar Prabu, Mangkunegara, 2000, Manajemen Sumber Daya Manusia perusahaan, Bandung: PT Remaja Rosdakarya.

Dindin Jamaluddin, “Character Education In Islamic Perspective”,dalam International Journal Of Scientific \& Technology Research,Volume 2, Issue 2, February 2013 ISSN 2277-8616.

Dwirandra, 2007, Pengaruh Interaksi Ketidakpastian Lingkungan, Desentralisasi. 
62 | Ivan Riyadi Manajemen Strategi Ekonomi Pada Lembaga Pendidikan Islam.....

Fanny Paylosa, 2014, Pengaruh Strategi Bisnis dan Desentralisasi Terhadap Hubungan Antara Pemanfaatan Informasi Sistem Akuntasi Manajemen Dan Kinerja Manajerial, fakultas ekonomi padang: Padang.

Hutomo mardi yatmo, 2000, Pemberdayaan masyarakat dalam bidang ekonomi: tinjauan teoritik dan Implemtasi, Seminar pemberbayaan masyarakat. Bappenas. Jakarta.

M.ParnawaPutranta, 2003, Manajemen, Yogyakarta:Andi.

Martinis Yamin dan Maisah, 2010, Standarisasi Kinerja Guru, Jakarta: Gaung Persada

Melayu S.P Hasibuan, 2001, Manajemen Dasar, Pengertian Dan Masalah, Jakarta, Bumi Aksara.

Muhaimin, dkk, 2009, Manajemen Pendidikan: Aplikasi dalam penyusunan rencana sekolah/madrasah, Jakarta: Kencana.

Nanang Fattah, 2004, Landasan Manajemen Pendidikan, Bandung: PT Remaja Rosdakarya.

R.L.MathisdanJ.H.Jackson， 2002， ManajemenSumberDayaManusia,Jakarta,Salemba Empat.

Rahayu Puji Suci. 2009, Peningkatan Kinerja Melalui Orientasi Kewirausahaan, Kemampuan Manajemen, dan Strategi Bisnis (Studi Pada Industri Kecil Menengah Bordir Di Jawa Timur), Jurnal manajemen kewirausahaan, vol 11. No.1.

Sondang P. Siagian, 2002, Manajemen Sumber Daya Manusia, Jakarta: Bumi Aksara

T. Hani Handoko, 2003, Manajemen Yogyakarta : UGM.

Weinata Sairin, 2001, Pendidikan Yang Mendidik, Jakarta: Yudhistira.

Zamzam, Fakhry dan Havis Aravik, Manajemen SDM Berbasis Syariah, Bogor: RWTC Success. 